\title{
Financial Literacy Versus Digital Literacy as a Predictor of Student Entrepreneurs Behavior in The Era of the Covid 19 Pandemic
}

\author{
Susanti ${ }^{1, *}$, Renny Dwijayanti ${ }^{1}$, Han Tantri Hardini ${ }^{1}$, Moh. Danang Bahtia ${ }^{1}$ \\ ${ }^{1}$ Faculty of Economics and Business, Universitas Negeri Surabaya, Surabaya, Indonesia \\ *Corresponding author.Email: susanti@unesa.ac.id
}

\begin{abstract}
This study aims to analyze the entrepreneurial behavior of students who are influenced by financial literacy and digital literacy. The population used in this study were young entrepreneurs at the Faculty of Economics, Unesa, amounting to 400 students. Sampling using purposive sampling by determining the number of samples using the Slovin formula with a total of 200 respondents. The instruments used in early research are questionnaires and questionnaires. The technique used is the analysis of reliability test, validity test, classical assumption test, and multiple regression test. The results showed that financial literacy and digital literacy had an effect on student entrepreneurship behavior during the covid 19 pandemic.
\end{abstract}

\section{Keywords: Financial Literacy, Digital Financial, Entrepreneurial Behavior}

\section{INTRODUCTION}

Economic development in Indonesia will increase if all economic indicators work together to create changes for the better. One of them is the efforts of the community and government to eradicate poverty caused by unemployment. People who have a strong entrepreneurial spirit to keep trying and work hard can change the country's economic conditions for the better. Entrepreneurs can turn obstacles into opportunities, provide new business opportunities for other job seekers, and can eradicate poverty.

Students as the next generation of the nation should actively participate and participate to be able to compete in the world of work. The future of students after graduating from college does not have to always look for work to work in certain agencies, but the hope is that they can provide jobs for others by entrepreneurship. Based on data from the Central Statistics Agency (BPS) regarding unemployment in Indonesia, graduates from universities are still very high. Below are data on unemployment for higher education graduates.

Based on the data above, the Central Statistics Agency (Badan Pusat Statistik) has data that shows open unemployment which is motivated by college graduate students that unemployment that occurs every year increases. Various efforts have been made to foster interest and intention in entrepreneurship, especially changing the minds of young people who have only intended as job seekers after completing their school or college to become job creators [12]. In dealing with development problems, higher education is not only required to proactively participate in shortterm development, but also must pay deep attention to noble ethics and morals such as educating students to have entrepreneurial principles [10]. With the entrepreneurship learning that has been taken in lectures, it can be used as capital or guidance by students for entrepreneurship. Entrepreneurial students no longer depend on existing jobs, but they think about how to create their jobs.

Table 1. Open Unemployment Rate by Category of University Graduates in 2017-2020

\begin{tabular}{|c|c|c|}
\hline No. & Year & Unemployment \\
\hline 1 & 2017 & 618,758 \\
\hline 2 & 2018 & 740370 \\
\hline 3 & 2019 & 746,354 \\
\hline 4 & 2020 & 981.203 \\
\hline \multicolumn{2}{|c|}{ Total } & $3,086,685$ \\
\hline
\end{tabular}

Entrepreneurial behavior is a major factor in influencing the success of a business run by an entrepreneur [1]. Every action or decision of an entrepreneur to advance and develop a business in the future is planned and measured through entrepreneurial behavior. By having qualified entrepreneurial behavior, an entrepreneur will be able to maintain the continuity of his business. At the time of the Covid 19 pandemic, many entrepreneurs who were originally offline entrepreneurs used online 
applications to assist in their entrepreneurial activities. Online social media is a term describing various kinds of technology with their use binding the community in collaboration, the exchange of information, and interaction through messages using a web [7]. The existence of social media is very helpful in starting online entrepreneurship because it has several types of social media that can be used as tools and media in facilitating entrepreneurs.

Several factors are thought to influence entrepreneurial behavior, including the existence of entrepreneurial financial literacy. Financial literacy is knowledge about financial management [11]. A good level of understanding of financial management is needed for entrepreneurs so that the decisions taken by entrepreneurs can be effective and efficient. Financial literacy is the relationship of three concepts, namely financial knowledge, financial attitudes, and financial behavior [5]. With entrepreneurship, a person can get benefits that can be used to improve his economy, and people who can manage personal finances well, of course, can manage finances well too. This is in line suggesting that economic factors are one of the driving forces for a person to become an entrepreneur [19].

The factor that is thought to influence entrepreneurial behavior during the COVID-19 pandemic is digital literacy. The development of information technology gives rise to a digital world that is increasingly growing rapidly. This increases the emergence of creative economy actors and new business actors (Start-Up). The role of star-up actors is as a creator of new jobs for themselves and others. Some of these startup actors are students and young adults. The number of business startups initiated by startups generates a turnover of tens to tens of millions with the concept of creative business. Information technology and digital technology are used by business people. Because these startups are between 17-25 years old, their digital literacy skills are also very good. Digital marketing is mostly done by business people today. This is indicated by a large number of online shops and a large number of sellers in the marketplace and other e-commerce. With good digital literacy, an entrepreneur can see opportunities by using digital media, communication technology, and other information [4].

So that the formulation of the problem in this development research is:

1. Is there any influence of financial literacy on the entrepreneurial behavior of students of the Faculty of Economics and Business, Universitas Negeri Surabaya during the covid 19 period?

2. Is there any influence of digital literacy on the entrepreneurial behavior of the students of the Faculty of Economics and Business, Universitas Negeri Surabaya during the covid 19 period?
3. Is there a simultaneous influence between financial literacy and digital literacy on the entrepreneurial behavior of students of the Faculty of Economics and Business, Universitas Negeri Surabaya during the covid 19 period?

\section{METHOD}

The method in this study is quantitative. The population of this study consisted of 400 students who had passed the JAPRI (Jadi Pengusaha Mandiri) Unesa program. Based on the calculation of the Slovin formula, obtained a research sample of 200 respondents. The relationship between research variables can be shown in the following figure:

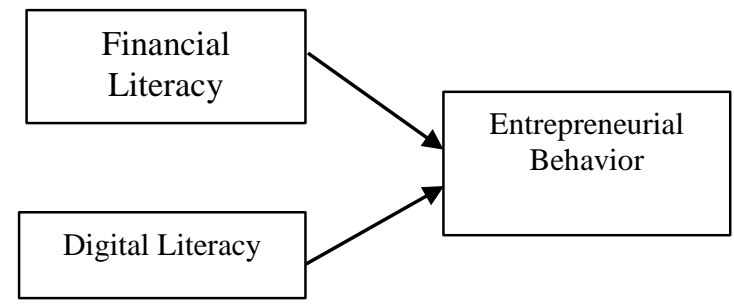

Figure 1 - Relationship between Research Variables

The research instrument for the financial literacy variable is a test of respondents' understanding of general knowledge of finance, savings, investment, loans, and credit with a total of 25 multiple-choice questions. Meanwhile, the instrument for digital literacy and entrepreneurial behavior variables uses 5 answer choices with a Likert scale. The Likert scale consists of $1=$ strongly disagree, $2=$ disagree, $3=$ quite, $4=$ agree, and $5=$ strongly agree.

Data collection techniques used online tests for financial literacy variables (X1), and online questionnaires for digital literacy variables (X2) and entrepreneurial behavior (Y). Data analysis technique using multiple linear regression. Based on Figure 1, the mathematical equation is as follows:

$Y=A+\beta 1 F L+\beta 2 D L+e$

(1)

Information:

$Y \quad$ : Entrepreneurial Behavior

A : Constant

$\beta 1, \beta 2 \quad$ : Regression Coefficient

$F L \quad$ : Financial Literacy

$F D \quad$ : Financial Digital

e $\quad$ : Standard error 


\section{RESULTS AND DISCUSSION}

\subsection{Research result}

3.1.1. Characteristics of Research Respondents

Entrepreneurial students at the Faculty of Economics and Business Unesa who have completed the JAPRI program conducted by the Faculty of Economics and Business Unesa comprised the research respondents. The data from the responders is shown in the table below

Table 2. Characteristics of Respondents

\begin{tabular}{|l|l|c|}
\hline No. & \multicolumn{1}{|c|}{ Majors } & Respondents \\
\hline 1 & Economic Education & 59 \\
\hline 2 & Management & 68 \\
\hline 3 & Accounting & 28 \\
\hline 4 & Economic & 45 \\
\hline & Number of Respondents & 200 \\
\hline
\end{tabular}

Based on table 2, it can be explained that there are 200 respondents from various departments at the Faculty of Economics and Business Unesa who are entrepreneurs.

Meanwhile, when viewed from the literacy level of the respondents, the following data were obtained as shown in Table 3.

Table 3. Respondents' Financial Literacy Level

\begin{tabular}{|c|l|c|}
\hline No. & \multicolumn{1}{|c|}{ Literacy Level } & Amount \\
\hline 1 & Low & 45 \\
\hline 2 & Currently & 98 \\
\hline 3 & Tall & 67 \\
\hline & Number of Respondents & 200 \\
\hline
\end{tabular}

Based on table 3, it is explained that the literacy level of respondents consists of low (60 respondents), medium (85 respondents), and high (55 respondents). Judging from the business carried out by students, it consists of:

Table 4. Type of Business occupied by Respondents

\begin{tabular}{|c|l|c|}
\hline No. & \multicolumn{1}{|c|}{ Type of business } & Amount \\
\hline 1 & Service Business & 55 \\
\hline 2 & Trading Business & 65 \\
\hline 3 & Manufacturing Business & 80 \\
\hline & Amount & 200 \\
\hline
\end{tabular}

Based on table 4, it is explained that of the 200 respondents who do service businesses, 55 students $(27.5 \%)$. The rest are doing business/trade business with 65 students $(32.5 \%)$ and manufacturing business with 80 students (40\%).

\subsubsection{Classic assumption test}

Before testing the regression data analysis, the classical assumption test was carried out, namely normality and multicollinearity tests.

Based on the results of the P-Plot in the SPSS output, it shows that the points are close to a straight line so it can be concluded that the data is normal. So it meets the normality test. Meanwhile, to find out that the data is free of multicollinearity, it can be shown by the results of the SPSS test with a VIF value of less than 10, so it can be concluded that the data is free of multicollinearity.

3.1.3. t-test

The t-test was used to answer the influence between research variables. Based on the results of the SPSS test, the t-test data is obtained in table 5 below:

Table 5. t-test results

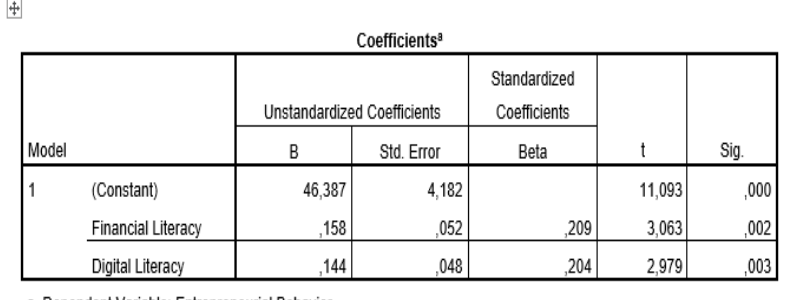

a. Dependent Variable: Entrepreneurial Behavior

Table 5 is used to test the hypothesis of the influence between variables. Based on these data can be explained as follows:

Ha 1: During the covid 19 period, there is an effect of financial literacy on the entrepreneurial activity of students at the Faculty of Economics and Business, Universitas Negeri Surabaya.

Based on the coefficient table above, the significance value is $0.02<0.05$ so that Hal is accepted. So it can be concluded that there is an influence between financial literacy variables on entrepreneurial behavior of students of the Faculty of Economics, Universitas Negeri Surabaya in the time of covid 19.

Ha 2: There is an influence between digital literacy on the entrepreneurial behavior of students of the Faculty of Economics and Business, Universitas Negeri Surabaya in the time of covid 19.

According to the coefficient table above, the significant value for the digital Literacy variable on student entrepreneurial behavior during the Covid19 epidemic is $0.03<0.05$, indicating that $\mathrm{Ha} 2$ is acceptable.. So it can be concluded that there is an influence between digital literacy variables on the entrepreneurial behavior of students of the Faculty of Economics and Business, Universitas Negeri Surabaya in the time of covid 19.

3.1.4. F test

To determine the congruence of the simultaneous relationship between study variables, the F test was 
performed. Table 6 displays the F test data based on the SPSS test results.

Table 6. F Test Results

\begin{tabular}{|c|c|c|c|c|c|c|}
\hline \multicolumn{7}{|c|}{ ANOVA $^{a}$} \\
\hline Mod & & Sum of Squares & df & Mean Square & $\mathrm{F}$ & Sig. \\
\hline \multirow[t]{3}{*}{1} & Regression & 934,083 & 2 & 467,041 & 10,568 & , $000^{8}$ \\
\hline & Residual & 8706,472 & 197 & 44,195 & & \\
\hline & Total & 9640,555 & 199 & & & \\
\hline
\end{tabular}

Ha 3: There is a simultaneous influence between financial literacy and digital literacy on the entrepreneurial behavior of students of the Faculty of Economics and Business, Universitas Negeri Surabaya in the time of covid 19

If the significance value in table 6 above is 0.00 0.05 , then $\mathrm{Ha} 3$ is acceptable. As a result, it is possible to infer that there is a concurrent relationship between financial literacy and digital literacy on the entrepreneurial behavior of students at the Faculty of Economics and Business, Universitas Negeri Surabaya during the period of covid 19.

\subsection{Discussion}

3.2.1. Financial Knowledge Affects the entrepreneurial activity of students at Universitas Negeri Surabaya's Faculty of Economics and Business during the covid 19 era..

The regression results show that the significance value between financial literacy variables on entrepreneurial behavior with a sign value of $0.00<$ 0.05. This shows that there is an influence between financial literacy on student entrepreneurship behavior during the Covid-19 pandemic. Financial knowledge is critical to living a wealthy life. It is intended that with adequate financial management, which is surely backed by solid financial literacy, their standard of life would improve; this applies to all income levels, because no matter how high a person's income level is, finances will be tough to accomplish [11]. Without financial knowledge and abilities, the potential of making mistakes in managing financial resources increases, and success is more difficult to acquire. Financial literacy in this study was measured by indicator (1). General knowledge about finance, (2). Income, (3). Savings, (4). Loans, and (5) investment, while entrepreneurial behavior can be seen from the indicators: (1). Innovation, (2). Courage to take risks, (3). Hard worker, (4). Flexibility to get along, (5). managerial ability and (6). Responsibility.
Based on the research findings, respondents who became entrepreneurs during the COVID-19 pandemic, felt confident in their entrepreneurship decisions both online and offline because they had financial knowledge. Financial knowledge includes how to use the money for good financial behavior as evidenced by purchasing decisions. However, not all respondents decided to buy because of their needs alone, but because of their desires with the interest in products offered online. This is of course if they do not have financial knowledge, respondents will buy products continuously, causing financial difficulties in the future.

The results of this study are consistent with previous studies explaining that financial literacy harms entrepreneurial behavior.

\subsubsection{Digital literacy on entrepreneurial behavior} of students of the Faculty of Economics and Business, State Universitas Negeri Surabaya during the covid 19 period

The regression findings suggest that the financial digital literacy variable has a significant value of $0.00<0.05$ on entrepreneurial behavior. This demonstrates that digital literacy has an impact on entrepreneurial activity during the Covid-19 epidemic. Digital literacy is the capacity to search for, access, evaluate, and produce information utilizing various types of digital technology in an effective and critical manner.

The capacity to interpret and use information from diverse digital sources is referred to as digital literacy [9]. Many items are now available through digital platforms, as digital technology evolves. Therefore, many respondents are literate in digital technology. In this case, the respondents are students who have more sophisticated technological facilities to carry out their business, for example in the form of mobile phones in which financial technology features are available, making it easier for entrepreneurship transactions. Digital literacy in this study is measured by (1).Internet Search, (2). Hypertextual Navigation, (3). Content evaluation (4). Knowledge Assembly. According to respondents, conducting entrepreneurial transactions online is much easier, faster, and safer than contracting the Covid 19 virus. Especially during the pandemic, respondents saw business opportunities related to consumer behavior to switch to online transactions. This is in accordance with research during the Covid-19 pandemic, that there is a significant trend of changes related to consumer behavior. As many as 50 percent of Indonesians have begun to reduce their activities outside the home and 30 percent of them admit that they plan to shop online more often. The desire to shop online is expected to continue to increase along with compliance with 
government regulations to maintain health, reduce crowds.

The findings of this study reveal that digital literacy has a partly positive and considerable influence on student entrepreneurial behavior in the period of the covid 19 epidemic. The results reveal that entrepreneurial behavior is influenced by how high the level of student digital literacy is well seen from the respondents' responses. The findings of this study confirm Gilster's [8] earlier notion that digital literacy is the capacity to use technology and information from digital devices effectively and efficiently in a variety of situations such as academics, careers, and daily life.

\subsubsection{Financial Literacy and Digital Literacy have} a simultaneous effect on the entrepreneurial behavior of the Faculty of Economics and Business, Universitas Negeri Surabaya during the covid 19 period

Based on the findings of the data analysis, it is possible to conclude that there is a concurrent effect of financial literacy, financial technology, and digital promotion on online purchases during the covid 19 epidemic. So it can be concluded that the relationship between variables in the research sample can apply to the population in this study.

\section{CONCLUSION AND SUGGESTION}

Based on the results of the study, it can be concluded that there is an influence between financial literacy and digital literacy on entrepreneurial behavior during the covid 19 pandemic. This research implies that the impact of covid 19 has influenced entrepreneurs to continue to run their business amid the ongoing pandemic in various ways including Entrepreneurs switching from offline to online entrepreneurs because they already have good digital literacy. Therefore, there is a need for education about financial literacy and digital literacy for entrepreneurial owners so that they can behave wisely. Good entrepreneurial behavior during the pandemic is caused by good financial knowledge and the ability to use digital applications. This is also protected so that there will be no future difficulties in using finances. In addition, education about digital literacy, will reduce misuse and reduce the impact of crime from others due to ignorance of the procedures for using digital systems.

\section{ACKNOWLEDGMENTS}

We would like to appreciate the lecturers and students from Universitas Negeri Surabaya's Faculty of
Economics and business for their willingness to assist with this research.

\section{REFERENCES}

[1] Aina, Arifah Q., et al. (2018). Factors Influencing Mompreneur Entrepreneurial Behavior (Case Study: Online Mother Community). Journal of Agribusiness Forum Vol.8, No.1, pp. 17-34.

[2] Artaya, I Putu, and Tubagus Purworusmiardi. "Marketplace Effectiveness in Increasing Concentration of Marketing and Product Sales for MSMEs in East Java" (nd).

[3] Baron, Robert A. (2007). Behavioral And Cognitive Factors In Entrepreneurship: Entrepreneurs As The Active Element In New Venture Creation. Strategic Entrepreneurship Journal, Vol.1, p.167182.

[4] Bayrakdaroglu, Funda and Ali Bayrakdaroglu. (2017). A Comparative Analysis Regarding The Effect of Financial Literacy and Digital Literacy on Internet Entrepreneurship Intention. Journal of Entrepreneurship and Development, Vol.12, No.2, p.27-38.

[5] Bryce L. Jorgensen and Savla Jyoti. 2010. Financial literacy of young adults: The importance of parental socialization. Family Relations Interdisciplinary Journal of Applied Family Science, Vol.59 Issue.4, pp 465-478.

[6] Botsaris, C., \& Vamvaka, V. (2014). Attitude Toward Entrepreneurship: Structure, Prediction from Behavioral Beliefs, and Relation to Entrepreneurial Intention. Journal of Knowledge Economy, 1(11), 1-28.

[7] Cross, Michael. 2013. Social Media Security. $1^{\text {st }}$ Edition Leveraging Social Networking While Mitigating Risk.Syngress.

[8] Herlina, S. 2012. Building National Character Through Digital Literacy. http://staff.uny.ac.id/sites/default/files/pengabdian/dyna-herlina-suwartomsc/mengbangun-character-bangsa-throughliterasi-digital.pdf. Accessed on January 2, 2021

[9] Heriyanto. (2018). Digital Media Literacy Competency, Vol. 5, No. 2, 8:09

[10]Laguador, JM (2013). Developing Students Attitude Leading Towards A Life Changing Career. Educational Research International, 1(3), 28-33.

[11]Latifiana, Dwi. 2016. Financial Literacy Study for Small and Medium Enterprises (UKM). Journal of FKIP Vol.3 No.1.

[12] Lawan, U. M. (2015). Perceptions and Attitude towards Entrepreneurship Education Programme, 
and Employment Ambitions of Final Year Undergraduate Students in Kano, Northern Nigeria 12. Journal of Education and Research, 3(11), 229242.

[13] Opponent, UM (2015). Perceptions and Attitude towards Entrepreneurship Education Programme, and Employment Ambitions of Final Year Undergraduate Students in Kano, Northern Nigeria 12. Journal of Education and Research, 3(11), 229242.

[14] Oyeumi, \& Adeniyi. (2013). Assessing Attitude To and Knowledge of Entrepreneurship Among Students with Hearing Impairment in Nigeria. Multidisciplinary Journal, 7(30), 127-142.

[15] Pradana, Mahir. "Classification of the Types of ECommerce Businesses in Indonesia." Journal of Neo-bis 9, no. 2 (December 2015).

[16] Shah, N., \& Ali, B. (2013). Investigating Attitudes and Intentions among Potential Entrepreneurs of a Developing Country: A Conceptual Approach. Journal of Business, 217-220

[17] Suryana. (2013). The Creative Economy, The New Economy: Changing Ideas and Creating Opportunities. Jakarta: Four Salemba.

[18] Yustiani, Rini and Yunanto, Rio. (2017). The Role Of Marketplace As A Business Alternative In The Era Of Information Technology. Scientific Journal of Computers and Informatics (KOMPUTA). Vol. 6, No. 2, October 2017, ISSN : 2089-9033

[19]Zimmerer, Thomas W., Norman Scarborough. (2008). Introduction to Entrepreneurship and Small Business Management. Jakarta: Four Salemba. 